\title{
To postkort fra Roskilde
}

\section{Peter LAUgesen}

Idiot wind, blowing through the dust upon our shelves.

Bob Dylan

1

Af og til et øjeblik

eller to eller tre

kan jeg kaste min stemme

, ud af mørket

Ord kan bære det bort

der tynger og kvæler

se hvor det flyver

som fugle der vender tilbage

til det sted de kom fra

nattens sovende fugle

dem der stråler i drømme

tusinde farver og flere

end der er hår på en hund

Men hvor er pulsens

vilde heste løbet hen?

Hvor er min brynje

af flåede mikrofoner? 
2

For de jager dem jo

på de udstrakte festivalsletter

de kvæler dem i deres ledninger

og af de små runde kroppe

syr de beskyttende dragter

mod lyden og lyset

mod hjertets dunken

mod sceneskræk

mod bagrusens hvide

fingre af daggry

i den blodrøde nat

De skælvende små

kloder af tid

der har kysset

den hylende vind

af guds brændende lunger 